\title{
密度関数法による自由水表面流れ解析 のための体積補正法に関する研究
}

\author{
朝位孝二 $1 \cdot$ 坪郷浩一 2 \\ 1正会員 山口大学助教授 工学部社会建設工学科（干755-8611宇部市常盤台2-16-1） \\ E-mail:kido@yamaguchi-u.ac.jp \\ 2学生会員 山口大学大学院 理工学研究科 博士後期課程（同上）
}

\begin{abstract}
密度関数法は複雑で大規模な自由水表面問題に対して有力な手法の一つであるが，数值拡散により気液 界面のぼやけが生じ，その結果として体積保存性に問題が発生する. 坪鄉・朝位はその問題を解決するた めに密度関数法のための体積補正法を開発し, 安定に長時間の自由水表面流れの計算を可能としたが, 精 度的にまだ改善の余地があった。本研究では精度の向上を図るために坪郷・朝位らの方法に改良を加えた。 境界が固体壁で囲まれた閉じた領域を対象にして精度検証を行い，本論文で提案する手法の妥当性を検討 した.
\end{abstract}

Key Words : the density function method, volume correction method, advection term, mass conservation, gas-liquid two phase flow

\section{1.はじめに}

水表面の大変形を伴う流れの数值解析は界面追跡 法と界面捕捉法がある。界面追跡法は自由界面形状 を精度よく追跡するために計算格子を界面変形に追 従させながら解析する。一方, 界面捕捉法は計算格 子の再構成を必要とせず，大規模変形問題にも適用 が比較的容易であり自由水表面流れ解析において有 力な手法の一つである.

界面捕捉法の先駆的手法はVOF法である。VOF法 は液相部分のみを解き気相部分は解かない。一方, 近年では気液二相流を同時に解く手法が発展してお り，C-CUP法 ${ }^{1)}{ }^{2}$, ， Level set法 ${ }^{3)}{ }^{4}$, 4) 5)，密度関数 法6)などが代表例として挙げられる.

密度関数法では計算進行とともに液相体積の保存 の問題が生じる. 数值拡散により液相でも気相でも ない領域が計算進行とともに広がり, 結果として純 粋液相体積部分が減少し, 液相の初期体積が保存さ れない. Level set 法では再初期化の段階で体積保 存が満足されなくなる。したがって計算過程で生じ た液体・気体の体積誤差を補正する必要がある。

既往の体積補正の手法としては，Level set 法では 姫野らの手法 ${ }^{6)}$, VOF 法 ${ }^{7)}$ では桜庭らの手法が挙 げられる. 密度関数法については著者らの体積補正 法が挙げられる ${ }^{8)}$. 著者らはその手法の検証を閉じ た計算領域での二次元ダム破壊問題を対象に行った. そして体積補正を行うことで体積保存が大幅に改善
され，長時間安定に計算を進めることができること を示した。しかしながら体積保存の精度については まだ改善の余地が残されていた。

本論文は，文献 8）で提案した体積補正法に改善 を加え，体積補正法の向上を図ることを試みたもの である。

\section{2. 計算手法}

\section{(1) 基礎式}

基礎式は非圧縮性流体に対する連続式，運動方程 式, 密度の保存式から構成される。

$$
\begin{gathered}
\nabla \cdot \mathbf{u}=0 \\
\frac{\partial \mathbf{u}}{\partial t}+\nabla(\mathbf{u} \cdot \mathbf{u})=\frac{1}{\rho}\left(\mathbf{F}-\nabla p+\mu \nabla^{2} \mathbf{u}\right) \\
\frac{\partial \rho}{\partial t}+\nabla \cdot(\mathbf{u} \rho)=0
\end{gathered}
$$

ここで $\mathbf{u}$ は流速ベクトル， $\rho$ は密度， $p$ は圧力， $\mu$ は 粘性係数, $\mathrm{F}$ は体積力である.

\section{(2) 密度関数}

密度関数法では式（3）を解く代わりに以下に示 す密度関数 $(0 \leq \Phi \leq 1)$ の保存則を解く.

$$
\frac{\partial \Phi}{\partial t}+\nabla \cdot(\mathbf{u} \Phi)=0
$$

ここでФは密度関数である。この関数は液相で 1 を, 気相で 0 を, 気液界面で 0.5 の值をとる. 


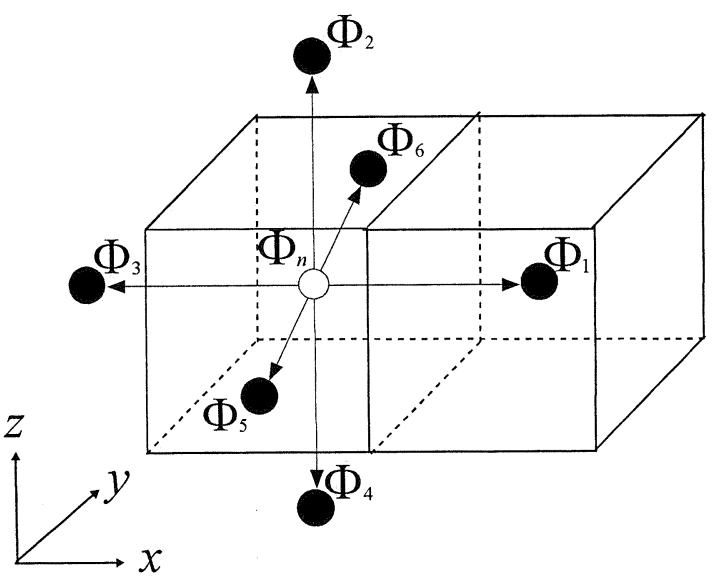

図-1 界面セルの判別

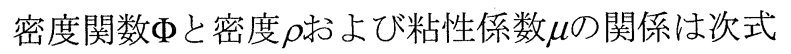
を用いる。

$$
\begin{aligned}
& \rho=\Phi \rho_{\text {Liq }}+(1-\Phi) \rho_{\text {Gas }} \\
& \mu=\Phi \mu_{\text {Liq }}+(1-\Phi) \mu_{\text {Gas }}
\end{aligned}
$$

ここで, $\rho_{L i q}$ は液相の密度, $\rho_{\text {Gas }}$ は気相の密度, $\mu_{L i q}$ は液相の粘性係数, $\mu_{\text {Gas }}$ は気相の粘性係数である.

\section{(3) 液相体積の計算}

液相体積の計算には計算セルの属性（液相セル, 気相セル，界面セル）を判別することが必要になる. そこで始めにセルの属性判別方法を説明する.

本論文では密度関数はセル中心で定義する. 各計 算セル中心の $\Phi$ 值に応じて, $\Phi>0.5$ のとき液相セル, $\Phi<0.5$ のとき気相セル, $\Phi=0.5$ のとき気液界面セル と判別する. また， $\Phi=0.5$ の等值線が通過するセル も気液界面セルとする． $\Phi=0.5$ の等值線が通過する セルは以下のように判断する。 なお, 計算格子間隔 は各方向でそれぞれ一定とする。

図-1 に示寸ようにセル $n$ と周囲 6 個のセルを考 える. 各セルの密度関数の值を $\Phi_{n}, \Phi_{k}(k=1 \sim 6)$ と する．セル $n$ に $\Phi=0.5$ の等值線が通過するか否かを 次のように判定する. セル $n$ とセル $k$ に関して, $\Phi=0.5$ が存在する無次元距離 $l(k)$ はセル $n$ の中心か ら以下のように与えられる.

$$
l(k)=\frac{0.5-\Phi_{k}}{\Phi_{k}-\Phi_{n}}
$$

界面セルは式 (7)を用いて以下のようにして判別さ れる。

( i ) $\Phi_{n}<0.5$ かつ $\Phi_{k} \geqq 0.5$ のとき

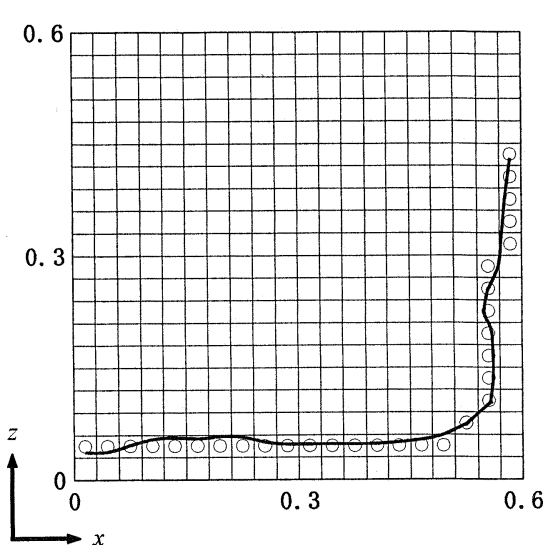

図-2 奥行き中央での鉛直断面 $(x-z$ 平面) における界面セルの判別の一例

$\left\{\begin{array}{l}l(k)<0.5 \text { であればセル } n \text { が界面セル } \\ l(k) \geq 0.5 \text { であればセルkが界面セル }\end{array}\right.$

(ii ) $\Phi_{n}>0.5$ かつ $\Phi_{k} \leqq 0.5$ のとき

$\left\{\begin{array}{l}l(k) \leq 0.5 \text { であればセル } n \text { が界面セル } \\ l(k)>0.5 \text { であればセル } k \text { が界面セル }\end{array}\right.$

界面セルの把握状態の一例を図-2 に示す. 図中 の太線が $\Phi=0.5$ の等值線を表し, 丸印が上記のアル ゴリズムで判別した界面セルを表す．図-2 より本 アルゴリズムは界面セルを的確に判別していること が分かる.

現在時刻 $t$ の液相体積 $V_{L i q}(t)$ は次式で求められる.

$$
V_{L i q}(t)=\iiint D(\Phi) d x d y d z
$$

ここで, $D(\Phi)=\left\{\begin{array}{cr}1 & \cdots \text { 液相セル } \\ \Phi(x, y, z, t) & \cdots \text { 界面セル } \\ 0 & \cdots \text { 気相セル }\end{array}\right.$

\section{(4) 体積補正}

本研究で提案する体積補正法 ${ }^{8)}$ の具体的な手順は 以下の通りである.

まず式(10)を行いて現在時刻 $t$ の液相体積 $V_{L i q}(t)$ を計算する．初期液相体積を $V_{L i q}(0)$ とおけげ，現在 時刻 $t$ の体積誤差 $V_{E r r}(t)$ は次式で表せる.

$$
V_{E r r}(t)=V_{L i q}(t)-V_{L i q}(0)
$$

計算領域内の界面セルの総体積を $A(t)$ とし, 式 （12）を用いて体積補正量 $L_{E r r}$ を求め，式（14）, （15）のような操作を行って補正を行う. 


$$
\begin{gathered}
L_{E r r}=\frac{V_{E r r}(t)}{A(t)} \\
A(t)=\iiint S(\Phi) d x d y d z
\end{gathered}
$$

ここで, $S(\Phi)=\left\{\begin{array}{l}0 \cdots \text { 液相セル } \\ 1 \cdots \text { 界面セル } \\ 0 \cdots \text { 気相セル }\end{array}\right.$

$L_{E r r}<0$ の場合

$$
\Phi^{n+1}=\left\{\begin{array}{l}
\Phi^{n+1}+\left|L_{E r r}\right| \cdots \text { 界面·液相セル } \\
\Phi^{n+1}-\left|L_{E r r}\right| \cdots \text { 気相セル }
\end{array}\right.
$$

$L_{E r r} \geq 0$ の場合

$$
\Phi^{n+1}=\left\{\begin{array}{l}
\Phi^{n+1}-\left|L_{E r r}\right| \cdots \text { 界面・気相セル } \\
\Phi^{n+1}+\left|L_{E r r}\right| \cdots \text { 液相セル }
\end{array}\right.
$$

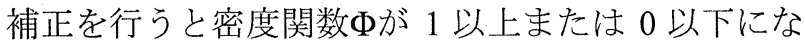
る場合がある。この場合，1 以上の值であれば 1 に， 0 以下の値であれば 0 にする.

\section{(5) 質量補正}

体積補正法が逆に計算領域内の全質量保存を破綻 させてしまう可能性がある。そこで質量補正のアル ゴリズム ${ }^{8)}$ を導入した。

まず，現在時刻 $t$ の計算領域内の全質量 $M(t)$ を計 算する. 本研究では密度と $\Phi$ 值は 1 対 1 の関係があ るので，Ф值を計算領域内で積分すれば良い。初期 全質量を $M(0)$ とおけば, 現在時刻 $t$ の質量誤差 $M_{E r r}(t)$ は次式で表せる.

$$
M_{E r r}(t)=M(t)-M(0)
$$

次に界面近傍の $0<\Phi<1$ となる領域 $\Omega_{\mathrm{M}}$ の体積 $A_{M}$ を次 式で求める。

$$
A_{M}(t)=\iiint S_{M}(\Phi) d x d y d z
$$

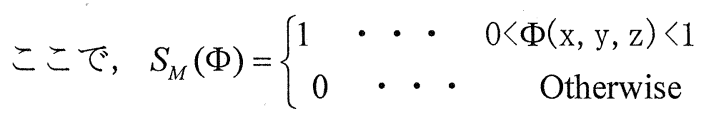

質量補正量 $M_{E r r}$ は以下のようにして求まる.

$$
M_{E r r}=\frac{M_{E r r}(t)}{A_{M}(t)}
$$

$M_{E r r}$ は領域 $\Omega_{\mathrm{M}}$ の単位セル当たりの質量補正量であ る. 式（19）のように領域 $\Omega_{\mathrm{M}}$ 内のセルから $M_{E r r}$ を 一様に差し引くことで補正される.

$$
\Phi^{n+1}=\Phi^{n+1}-M_{E r r}
$$

文献 8）では，各時間ステップで上述の体積補正

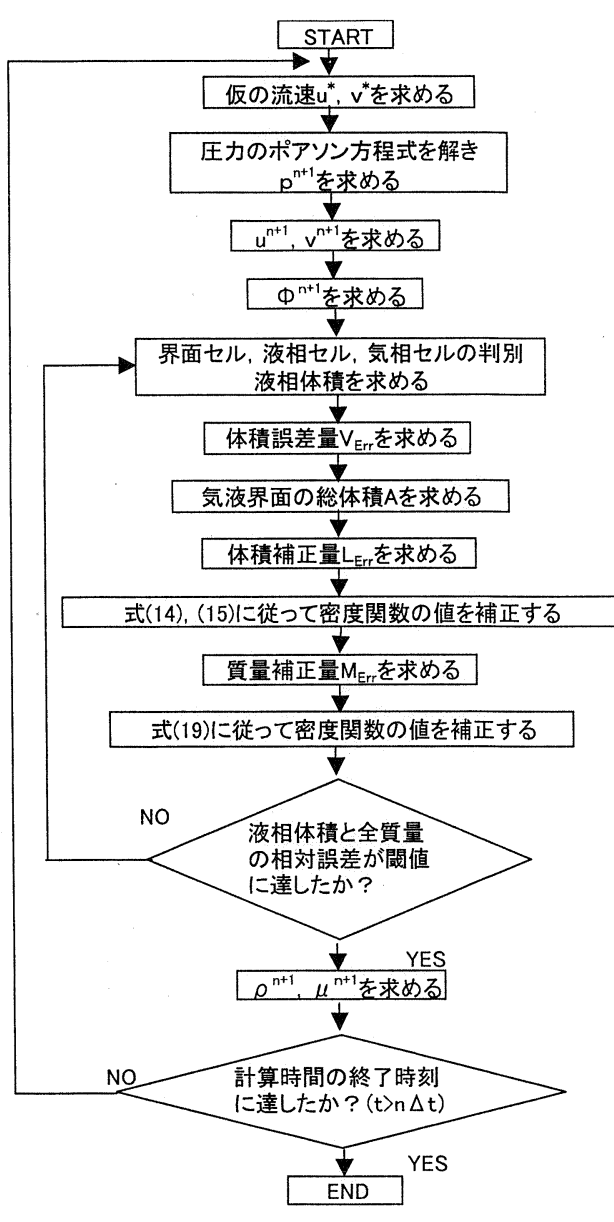

図-3＼cjkstart計算アルゴリズムのフローチャート

と質量補正を一度だけ行うことにしていた，補正を 施さない場合と比較して大幅な体積保存の向上を確 認できたが，保存の精度にはまだ改善の余地がある. そこで，本研究では図-3 のフローチャートに示し ているように，体積補正と質量補正を交互に繰り返 すループを導入した. 液相体積および全質量の相対 誤差に対する閾值をそれぞれ設定し, それぞれの誤 差が各閾值を下回るまでループを回り続ける。実際 のプログラミングでは，無限ループにならないよう に繰り返しの最大值を設定し, それを越えると計算 を止めるなどの工夫は必要である.

なお，以降では前節の体積補正法とこの節の質量 補正法を合わせて体積補正法と呼ぶことにする.

\section{3. 体積補正法の検証}

\section{(1) 計算条件}

この章では自由水表面流れの検証問題の一つであ るダム破壊問題で体積補正法の効果の検討を行う。 初期条件として, 図-4 のように長さ $4 L$, 高さ $4 L$, 奥行き $L$ の水槽に長さ $L$, 高さ $2 L$, 奥行き $L$ の水 


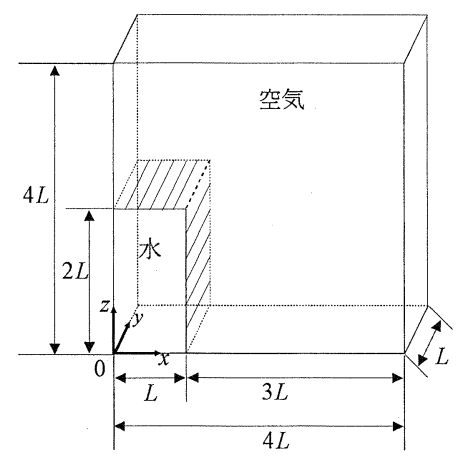

図-4ダム破壞モデル計算の初期配置

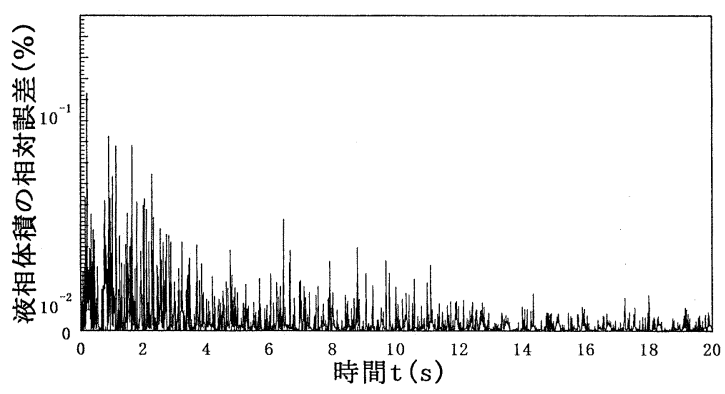

（a）液相体積の相対誤差

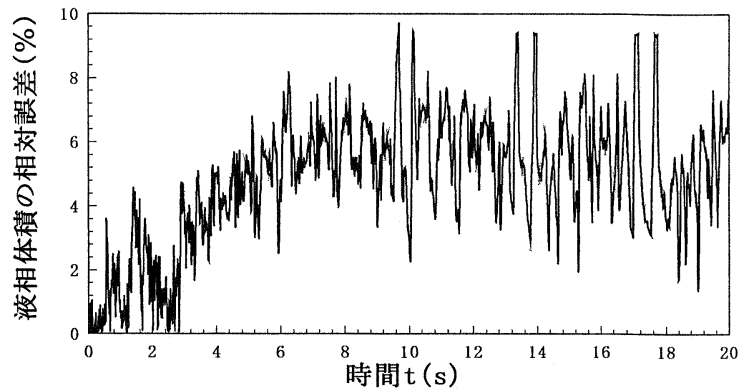

図-5＼cjkstart液相体積の相対誤差（体積補正法なし）

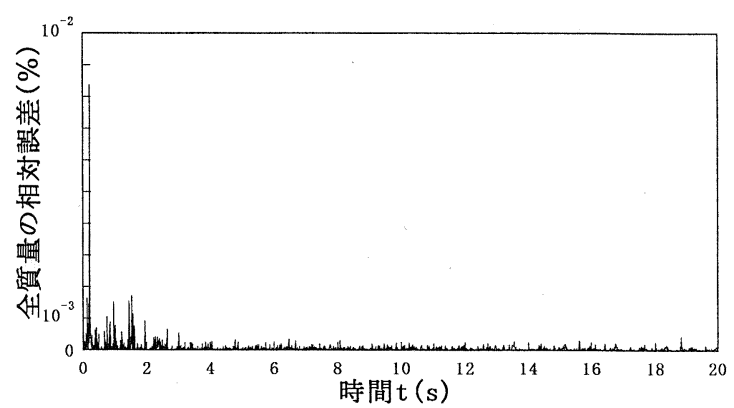

(b) 全質量の相対誤差

図-6 液相体積および全質量の相対誤差(体積補正法を各時間ステップで 1 回だけ適用。)

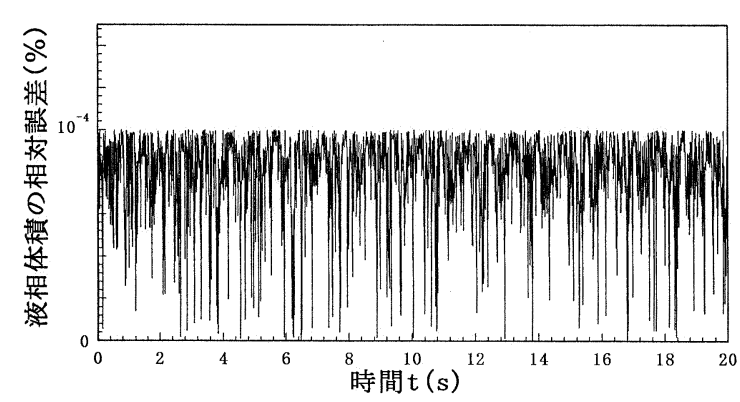

（a）液相体積の相対誤差

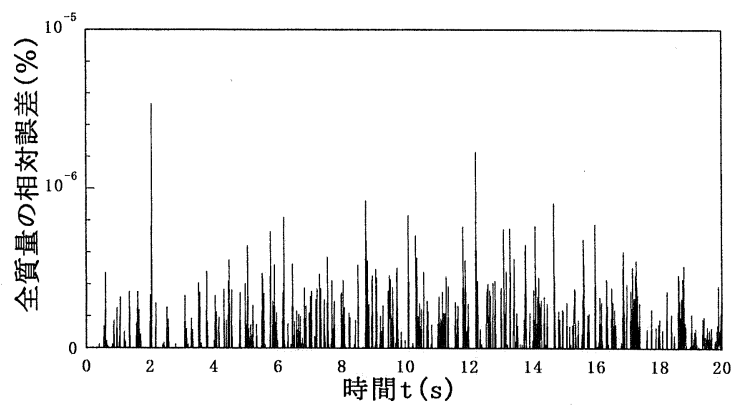

(b) 全質量の相対誤差

図-7 液相体積および全質量の相対誤差（体積補正法あり。閾值は 10-4\%)

柱を設定する．ここで， $L=0.15 \mathrm{~m}$ とした．水槽内に おける水柱破壊現象を崩壊開始から 20 秒後までを シミュレートした。液相は水, 気相は空気を想定し ている，計算格子間隔は $\Delta x=\Delta y=\Delta z=0.015 \mathrm{~m}$ ，時間刻 みは $\Delta t=0.0001 \mathrm{sec}$ で一定值とした，境界はすべて滑 りありの固体壁とした。

移流項計算スキームは, 運動方程式に 3 次精度 TVD-MUSCL 法 ${ }^{9)}$, 密度関数の移流方程式に朝 位らが開発した 3 次精度保存形式 6-point scheme ${ }^{10)}$ を用いた. 3 次精度保存形式 6-point scheme には数 值振動除去するために universal limiter ${ }^{11)}$ を導入して いる.

\section{(2) 検証結果}

まず，体積補正法を適用しない場合の結果につい て示す. 全質量の保存について検討する. 境界は固
体壁であるので初期全質量は保存される必要がある. 任意時刻の全質量と初期全質量の相対誤差は $10^{-13} \%$ 以内に収まった. 次に, 液相体積の相対誤差の検討 を行う. 式(10)で算出した液相体積の初期体積に対 する相対誤差の時間変化を図 -5 に示す. 相対誤差 は時間とともに増加し，20 秒後には相対誤差が約 $5 \%$ 程度となり体積保存は破綻している. 数值拡散の ために計算領域内には水でも空気でもない状態で存 在する領域が発生している.

体積補正法を適用した場合の結果を図-6，7 に示 す. 図-6 は体積補正法を各時間ステップで 1 回だ け適用した場合であり，文献 8）の方法に対応する. 図-6 において液相体積は図-5 と比較して大幅に改 善されていることが分かる.しかしながらスパイク 的に誤差が大きくなる箇所があり最大で $0.11 \%$ 程度 


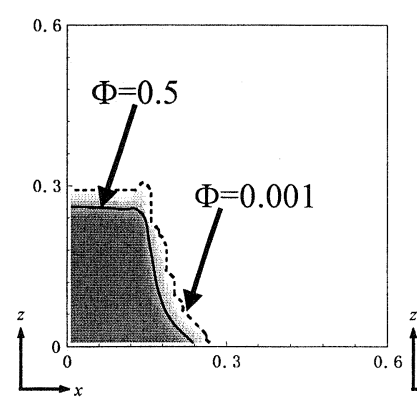

$\mathrm{t}=0.10 \mathrm{~s}$

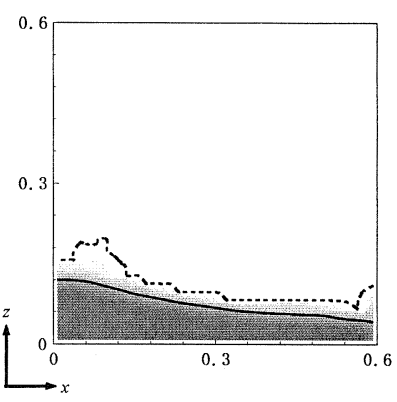

$t=0.30 \mathrm{~s}$

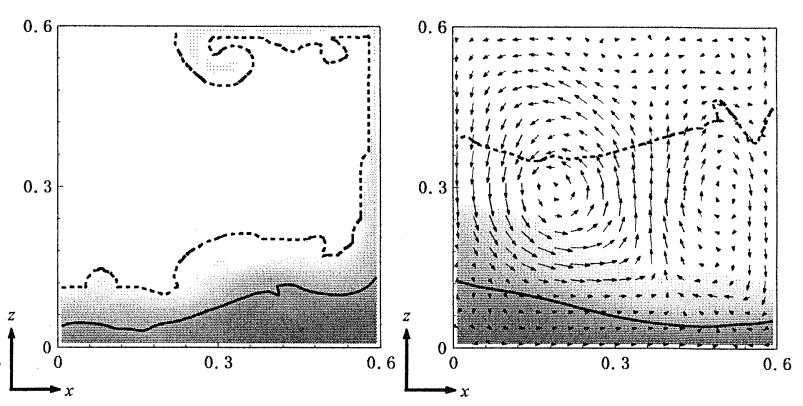

$t=2.0 \mathrm{~s}$

$\mathrm{t}=5.0 \mathrm{~s}$

(a) 体積補正法なし

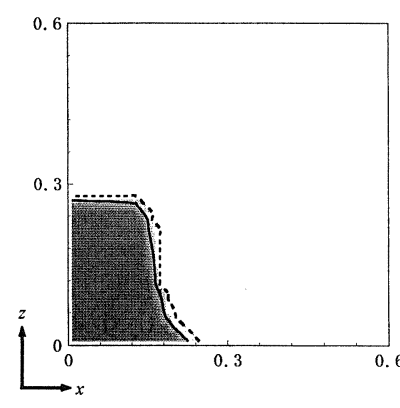

$t=0.10 \mathrm{~s}$

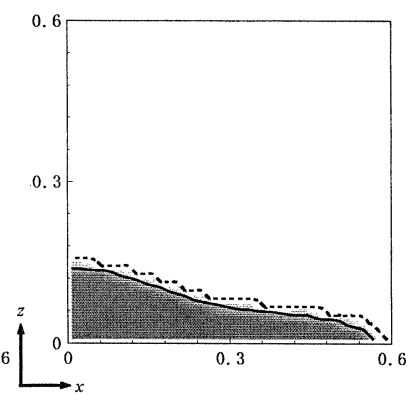

$t=0.30 \mathrm{~s}$

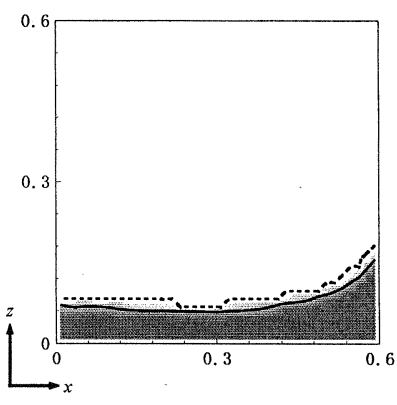

$t=2.0 \mathrm{~s}$

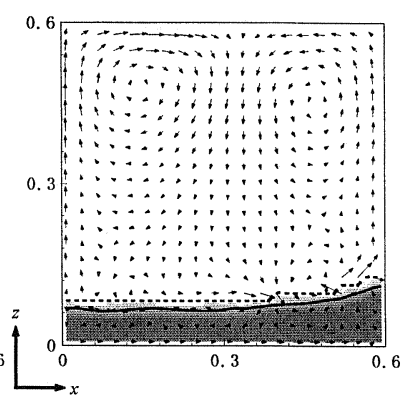

$t=5.0 \mathrm{~s}$

(b) 体積補正法あり

図-8 奥行き中央位置を通過する鉛直断面における液相の挙動

になる。全質量は最大で $0.008 \%$ 程度の誤差が見られ る. 図-7 は液相体積と全質量の相対誤差の閾值を $10^{-4} \%$ に設定し繰り返し計算を行った結果を示してい る. 液相体積はすべて閾值以下となっており精度の 改善が見られる。また全質量に関しても $10^{-5} \%$ 以下 の誤差に収まっている.

図-8に奥行き中央位置 $(y=L / 2)$ を通過する鉛直 断面 $(x-z$ 平面) における液相の挙動の一例を示す. 図中の太線の等值線が $\Phi=0.5$, 点線の等值線が $\Phi=0.001$ を表す. 塗りつぶしの色の濃淡は $\Phi$ 值の大 きさを表し, 最も濃い色は液相を, 白は気相を表す. $\mathrm{t}=5 \mathrm{sec}$ の図の夕, 流速ベクトルを重ねている. 体積 補正を施さない場合の結果を図-8(a)に示す. 数值 拡散によりФ值が広がっていく様子が分かる。 5 秒 では液相が減少し，体積保存が破綻している．本論 文の体積補正法を行った場合の結果を図-8(b)に示 す. 界面近傍の数值拡散が抑制され界面鋭敏化の効 果があることが分かる。

図-9に奥行き中央位置を通過する鉛直断面での 水柱先端位置の時間変化を示す. 体積補正法を施す ことで若干の先端速度の低下が見られる。

\section{4.おわりに}

本研究は, 坪郷・朝位らが提案した密度関数法に

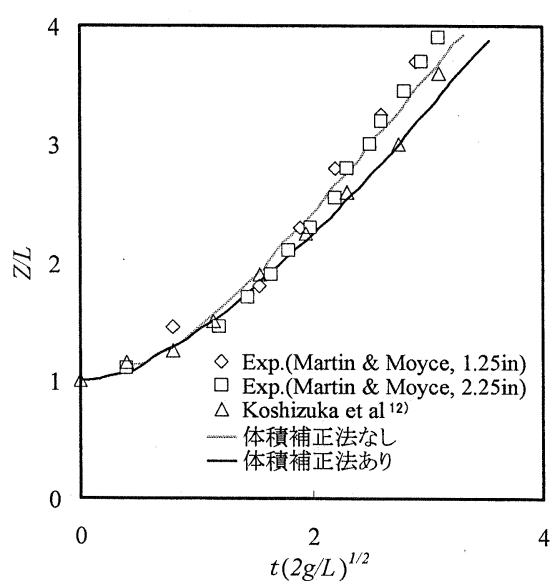

図-9 奥行き中央での鉛直断面における 水柱先端位置の時間的変化

よる自由水表面流れ解析のための体積補正法の改善 を行ったものである。体積補正と質量補正を交互に 繰り返すループを導入した。これにより体積保存と 質量保存の精度を向上させることが可能となった。 体積補正法の適用により体積保存の精度は向上する が，先端移動速度が遅れる傾向がある。

本論文では閉鎖的空間でのダム破壊問題で本手法 の妥当性を検討した．水工学では開水路のように流 入・流出のある開境界での問題が主である。このよ 
うな場への本手法の適用は，ある時間ステップでの 流入・流出量の収支から計算領域内の液相体積と全 質量を算出し, それをターゲットとして本手法を適 用すれば良いものと思われる。詳細は今後の課題と したい.

\section{参考文献}

1) Yabe, T. and Wang, P.-Y. : Unified numerical procedure for compressible and incompressible fluid, J.Physical Society of Japan, Vol.60, No.7, pp.2105-2108, 1991.

2）陸田秀実，河合ひろみ，安田孝志：C-CUP 法による 気液界面の直接数值計算, 海岸工学論文集, 第 45 巻, pp.55-59, 1998.

3) Sussmann, M., Smereka, P. and Osher, S. : A level set approach for computing solutions to incompressible two phase flow, J. Comp. Phys., Vol.114, pp.146-159, 1994.

4）由比政年, 石田啓, 保智正和：界面の大変形を伴う 気液二相流体場の数值解析, 海岸工学論文集, 第 45 巻, pp.61-65, 1998.

5）姫野武洋, 渡辺紀徳 : 微小重力環境における気液界 面挙動の数值解析, 日本機械学会論文集 (B 編), 65 巻 635 号, pp.147-154, 1999.

6）金井亮浩，宮田秀明：密度関数法を応用した気泡の
数值シミュレーション, 日本造船学会論文集, 第 179 号, pp.41-48, 1996.

7）桜庭雅明, 弘崎聡, 樫山和男 : 自由表面流れ解析の ための CIVA/VOF 法に基づく高精度界面捕捉法の構 築, 応用力学論文集, 6 巻, pp.215-222, 2003.

8）坪郷浩一, 朝位孝二: 密度関数法による自由水表面 流れ解析のための体積補正法の開発, 水工学論文集, 第 49 巻, pp.697-702, 2005.

9) 藤井孝蔵: 流体力学の数值計算法, 東京大学出版会, pp.72-76, 1994.

10) 朝位孝二, 坪郷浩一, 小松利光 : 特性曲線形式およ び保存形式高次精度 6-point schemeの開発, 土木学会 論文集, No. 803/II-73, pp.29-44, 2005.

11) Leonard, B. P. and Niknafs, H. S. : Sharp monotonic resolution of discontinuities without clipping of narrow extrema, Computers \& Fluids, Vol.19, No.1, pp.141-154, 1991.

12) 越塚誠一: 数值流体力学, 培風館, p.178, 1997.

\section{STUDY ON VOLUME CORRECTION METHOD FOR FREE SURFACE FLOW ANALYSIS USING DENSITY FUNCTION METHOD}

(2005. 7. 25 受付)

\section{Koji ASAI and Koichi TSUBOGO}

The density function method is one of the powerful tools for solving a complicated free surface flow problem. However, an air-water interface becomes dim due to a numerical diffusion and it leads conservation of fluid volume to fail. Tsubogo and Asai developed the volume correction method to avoid this problem. Although the long term computation for free water flow can be made by using this method, there is a room to improve their method. In this paper, the volume correction method proposed by Tsubogo and Asai is modified. The effect of the proposed method was checked by solving dam break problems with a whole closed boundary condition. It is found that the modified volume correction method is effective. 